\title{
To Delegate or Redelegate: Is THAT THE QUESTION?
}

\author{
Thomas Halper*
}

\begin{abstract}
Conflicts between those supporting and opposing congressional redelegation to executive agencies go back to the earliest days of the Republic, but given the enormous development of the administrative state, now raise issues of great practical importance. The arguments back and forth implicate abstract notions of democracy, efficiency, and judicial power, though typically partisan and other self interested considerations actually drive the debate. The future is likely to see some retrenchment, but not wholesale rejection of redelegation, as the massive and unpredictable consequences would deter courts from acting.
\end{abstract}

\section{KEYWORDS}

Delegation, Redelegation, Chevron v. Natural Resources Defense Council

\section{CONTENTS}

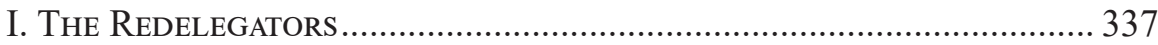

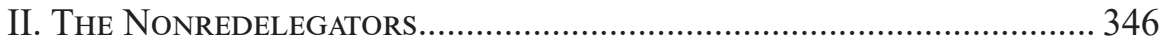

III. LOOKING TO THE FUTURE _.......................................................... 353

* Baruch College/CUNY \& CUNY Graduate Center 
We begin with a maxim. Delegata potestas non potest delegari. No delegated power can be further delegated. ${ }^{1}$ The reason lies in the problem of principal and agent. When a principal asks an agent to do something, he understands that the agent will have his own interests to advance and protect, but concludes that nonetheless he will complete a sufficient amount of the job to make the arrangement worthwhile. He carries my water in a leaky bucket, but enough arrives to satisfy me. ${ }^{2}$ But if the agent then redelegates the task, the connection with the original principal is severed. It is no longer his judgment that the agent will be satisfactory, but rather the judgment of the agent that his agent will be satisfactory. If the principal wanted the second agent to carry out the task, he would have chosen him. But he did not. The second agent, sloppy, clumsy, and drunk, might well have spilled most of the water. If the Constitution delegates a certain task to Congress, who then redelegates it to an agency, the problem is amplified because neither Congress nor the agency is an it with a singular, coherent purpose but rather a they with multiple purposes. ${ }^{3}$ This is the multiple principal problem.

Yet if we have serious reservations about the wisdom of redelegation, we also know that Congress is incapable of issuing the myriad of regulations that bring statutes to life. Here, we refer not to structural regulations that establish agencies and give them rule making or enforcement powers, but rather the endless substantive regulations that govern conduct, monitor compliance, auction licenses, and the like. Congress redelegates to agencies in the service of its multiple interests, but agencies act in the service of their own multiple interests.

Yet with the exception of a pair of cases decided some eighty-five years ago, ${ }^{4}$ courts have uniformly declined to enforce the ban on redelegation. Panama Refining Company v. Ryan (1935) involved the Petroleum Code of the National Industrial Recovery Act (1933), ${ }^{5}$ a pillar of the New Deal that created over 700 such codes with the purpose of bringing about economic recovery and reform. Section 9 (c) authorized the President to prohibit the interstate transportation of petroleum products and the removal of these products from storage in excess of the amounts permitted by state production quotas. The President issued executive orders creating a regulatory Petroleum Code and granting the Secretary of the Interior power to enforce it. Panama sued to restrain officials from enforcing these regulations.

Chief Justice Hughes, speaking for an eight vote majority, held that the statute gave "to the President an unlimited authority to determine the policy," in effect unconstitutionally granting him legislative power. ${ }^{6}$ (Justice Cardozo, dissenting, thought the law was clear enough and implied that the majority had proceeded with

The doctrine may have originated in a mistranslation of Bracton's De Legibus and thence through Coke to Kent and Story. Patrick W. Duff \& Horace E. Whiteside, Delegata Potestas Non Potest Delegari: A Maxim of American Constitutional Law, 14 CorN. L. Q. 168 (1929).

2 Cf. Arthur Okun, Equality and Efficiency: The Big Tradeoff (1975).

3 Kenneth A. Shepsle, Congress Is a "They," Not an "It": Legislative Intent as Oxymoron, 12 INT'L REv. L. \& ECON. 239 (1992).

$4 \quad$ Panama Refining Co. v. Ryan, 293 U.S. 388 (1935); Schechter Poultry Corp. v. U.S., 295 U.S. 495 (1935).

5 Petroleum Code of the National Industrial Recovery Act, 48 Stat. 195 (1933). In that year, President Roosevelt issued 593 executive orders to implement legislation.

6 Panama, supra note 4, at 415. 
"pedantic rigor." ${ }^{\prime 7}$ ) Schechter Poultry Corporation v. United States, concerning the NIRA's Live Poultry Code and decided barely four months later, saw Hughes offer the same argument against redelegation, citing the vagueness of terms like "unfair competition." 8

With only two cases upholding the principle of nondelegation, it is no wonder that Evan Zoldan called it "less a doctrine than a ghost story." Or that Cass Sunstein remarked, "We might say that the conventional doctrine has had one good year and 211 bad ones (and counting)." 10 The bad ones now total 232. How is this to be explained? What does the future hold?

In surveying the cases and the literature, two views predominate. The Redelegators simply ignore the nonredelegation prohibition as an anachronistic relic of the past or dismiss it as a myth. The Nonredelegators consider this rejection as heresy and would implement the nonredelegation rule in various guises.

\section{THE REDELEGATORS}

Redelegators ordinarily begin with four points. First, administrative rule making, monitoring, and enforcement are all unavoidable corollaries of the executive function derived from legislation itself. ${ }^{11}$ There are about 200 federal agencies that issue about 3,000 regulations per year; Congress may enact only about seventy-five laws during that time, but cumulatively the total number of laws also runs into the thousands. These regulations and laws, adopted at different times under different circumstances, often conflict or overlap, requiring administrative discretion to make all kinds of practical choices. Then, too, the ever present scarcity of resources demands priority setting, which also calls for administrative discretion. Furthermore, even if they had the time, experience, expertise, and interest, members of Congress still could not foresee all future factual circumstances, and would need administrators to fashion laws to fit the unforeseen situations.

Moreover, congressional and judicial action is slow, cumbersome, costly, and thus not very responsive to fast moving or unexpected events or developments; Congress and especially courts may also not be very good at fact gathering, being guided by different norms and possibly lacking in useful long term personal relationships. ${ }^{12}$ For a bill to become a law, it must be passed in identical form by both houses, after surviving a gauntlet of committee and subcommittee approvals, and be signed by the President; sometimes, this process must be repeated in order to secure appropriations. As for the judiciary, it may also take years for a case to wind its way from trial to the Supreme Court, that is, if it is fortunate enough to be selected among the $1 \%$ of certiorari petitions that the Court accepts. Furthermore, though Presidents differ as to

\footnotetext{
Id. at 440 .

8 Schechter supra note 4, at. 531. The Court also found that the code violated the commerce clause.

9 Evan C. Zoldan, The Fifth Vote for Non-Delegation, Jurist (Dec. 14, 2019), https:// www.jurist.org/commentary/2019/12/evan-zoldan-the-fifth/.

10 Cass R. Sunstein, Nondelegation Canons, 67 U. CHI. L. Rev. 315, 322 (2000).

11 Thomas W. Merrill, Rethinking Article I Section 1: From Nondelegation to Exclusive Delegation, 104 Col. L. Rev. 2097, 2101 (2004).

12 Kathryn A. Watts, Rulemaking as Legislating, 103 Geo. L. J. 1003, 1005 (2015).
} 
the qualities they look for in their judicial appointees, one factor they nearly always insist on is support for strong presidential authority. Thus, neither Congress nor the courts can be counted on as strong and reliable barriers against redelegation.

Hence, the common observations that implementation "necessarily involves a considerable amount of policymaking," 13 and that "administrative lawmaking has become a central, defining feature of the modern administrative state." ${ }^{14}$ Rule making and legislation, in any case, are functionally indistinguishable; the former fills in the details, completing the latter. ${ }^{15}$ Indeed, Justice Sotomayor commented that agency regulations "are often referred to as 'legislative rules' because they have the "force and effect of law."'16 As to the agencies, they "owe significant 'faithfulness' to Congress. Congress breathes them into being and endows them with purpose and authority." 17

Second, because of this practical necessity, the nonredelegation doctrine is said to have no real history. Keith Whittington and Jason Juliano conclude that "there was never a time in which the courts used the nonredelegation doctrine to limit legislative delegations of power."18 Matthew Adler reassures us that "the nonredelegation doctrine remains dead." 19 Julian Mortenson and Nicholas Bagley advise, "Forget the debate over whether the nonredelegation doctrine is truly dead. It was never really alive to begin with." ${ }^{20}$

Redelegators prefer, instead, to speak of sleep. Hobbes in On the Citizen writes of a sleeping sovereign, whose ministers do not assume his sovereignty as their own, but merely implement the orders he gave before he went to sleep. ${ }^{21}$ By analogy, the people, who collectively constitute America's supreme political authority, delegate their powers via the Constitution to Congress, which (also given to sleep) redelegates them to government agencies. In this way, the thread connecting sovereign to regulations remains unbroken.

The most careful historical inquiry, Creating the Administrative Constitution (2012) by Jerry Mashaw, confirms this narrative, confounding the conventional view that once upon a time the federal government was run by a Congress that wrote "virtually self-executing laws." 22 As Mashaw tells it, the Articles of Confederation

13 Edward Rubin, The Myth of Accountability and the Anti-Administrative Impulse, 103 Mich. L. Rev. 2073, 2094 (2005).

14 Evan J. Criddle, When Delegation Begets Domination: Due Process of Administrative Lawmaking, 46 GA. L. Rev. 117, 120 (2011).

15 Jack Goldsmith \& John F. Manning, The President's Completion Power, 115 Yale L. J. 2280, 2282 (2006).

16 Perez v. Mortg. Bankers Ass'n., 135 S. Ct. 1199, 1203 (2015).

17 Robert R.M. Verchick, Toward Normative Rules for Agency Interpretation: Defining Jurisdiction Under the Clear Water Act, 55 Ala. L. Rev. 845, 850 (2004).

18 Keith E. Whittington \& Jason Juliano, The Myth of the Nondelegation Doctrine, $165 \mathrm{U}$. PA. L. Rev. 379, 381 (2017).

19 Matthew D. Adler, Judicial Restraint in the Administrative State: Beyond the Countermajoritarian Difficulty, 145 U. PA. L. Rev. 759, 839 (1997).

20 Julian Davis Mortenson \& Nicholas Bagley, Delegation at the Founding, 121 Colum. L. Rev. 277, 285 (2021).

21 Thomas Hobbes, On the Citizen 99-100 (Richard Tuck \& Michael Silverthorne eds. 1990) (1642).

22 Theodore J. Lowi, The End of Liberalism 94 (1969). See also, e.g., Morton J. Horowitz, The Transformation of American LaW, 1870-1960: The Crisis of Legal Orthodoxy 213-46 (1991); Gerald E. Frug, The Ideology of Bureaucracy in American 
Congress sought to administer government through a multitude of committees, but by the time of the Constitutional Convention, it was clear that a legislative body could not effectively perform executive functions. Thus, when the first post Constitution Congress created the departments of State and War, it said little beyond that they should do as the President instructed and adopt whatever rules he told them to adopt. ${ }^{23}$ "From the earliest days of the republic, Congress delegated broad authority to administrators, armed them with extrajudicial powers, created systems of administrative adjudication, and specifically authorized administrative rulemaking." 24

This embrace of broad redelegation followed not from abstract principle, but from practical necessity, experientially pursued. Even Presidents Jefferson and Jackson, ideologically appalled by the federal bureaucracy, found that they needed agencies operating with considerable discretion to distribute land from the Louisiana Purchase, implement the 1808 trade embargo, regulate navigation, and build hospitals for seamen. Agencies set down detailed rules guiding, incentivizing, and limiting their employees, and it is this "internal administrative law" and not judicial review that Mashaw finds was the chief means of accountability. In other words, agency driven administrative law, often with little congressional or judicial input, governed administration, reflecting the policy preferences of Presidents. ${ }^{25}$ Much later, nearly all the civil rights progress prior to the passage of the Civil Rights Act was also due to a series of executive orders that discouraged employment discrimination in the defense industry, ${ }^{26}$ desegregated the military, ${ }^{27}$ and promoted affirmative action. ${ }^{28}$

Mortenson and Bagley, in almost a book sized article, also conclude that the Framers took redelegation for granted, as long as Congress did not permanently forswear its power to legislate. They believe that the Framers "thought of constitutional powers in nonexclusive and relational terms," so that agencies would "absolutely wield legislative power to the extent they declare binding rules that Congress could have enacted as legislation." ${ }^{29}$ In the authors' eyes, the "nondelegation doctrine thus has nothing to do with the Constitution as it was

Law, 97 Harv. L. Rev. 1276 (1984); Richard B. Stewart, The Reformation of American Administrative Law, 88 HaRv. L. Rev. 1667, 1675 (1973).

23 Jerry Mashaw, Creating the Administrative Constitution: The Lost One Hundred Years of American Administrative Law 290-91 (2012). Tocqueville had pointed to the ubiquity of local administrators. 1 Alexis de Tocqueville, Democracy IN AMERICA 45, 53 (Henry Reeve trans., 2002) (1835).

24 Mashaw, supra note 23, at. 5. This redelegation even predated the "salary revolution," when other means of payment were common. Nicholas R. Parrillo, Against the Profit Motive: The Salary Revolution in American Government 1780-1940 (2013).

25 Id. 293

26 Exec. Order No. 8802 (1941).

27 Exec. Order No. 9981 (1948).

28 Exec. Order No. 10925 (1961).

29 Mortenson \& Bagley, supra note 20, at 282. The authors also dispute the originalists' contention that the founding generation distinguished between legislation that regulates private conduct and rulemaking that regulates official conduct. They claim that the early Congresses redelegated in both areas. 
originally understood." ${ }^{30}$ Not until Marshall Field v. Clark in 1892 did the Supreme Court so much as mention nonredelegation, and in this case it upheld a law against a nonredelegation challenge. ${ }^{31}$

Blake Emerson carries this further, arguing for the democratic potential of modern administration. In The Public's Law (2019), he shows that Progressives, influenced by Hegel's vision of the state as a vehicle for human freedom, believed that "the state must guarantee freedom through regulatory and welfare laws implemented by public-spirited officials." ${ }^{\prime 2}$ In envisioning agencies and the public interacting, Progressives bypassed Hegel's rejection of democracy and focused on his notion that officials were necessary to offer "the social and economic requisites people need to live their lives freely." 33 Emerson focuses most heavily on the New Deal and the civil rights period of the 1960s (which he calls the Second Reconstruction); both were more successful in involving the public in bureaucratic decision making, through such devices as notice and comment requirements, than in their material results, but had the bureaucracies been even more a "site for political discourse and not merely purely technical or economic reasoning," he thinks these shortfalls might have been ameliorated. Progressives valued apolitical knowledge and expertise, Emerson concedes, because they thought they produced better policies. But they also appreciated the importance of "a professionalism of spirit" ${ }^{\prime 34}$ and an ethical sense that would constrain officials faced with countless discretionary opportunities. ${ }^{35}$ Thus shaped, these agencies could then claim to speak for interests underrepresented in legislatures, and in this sense aggressively advance the democratic purpose.

Emerson would resolve the principal-agency problem through a kind of ethical collusion: If all parties are committed to the common good, the problem would be minimized. What he perhaps does not sufficiently emphasize is that there are a multitude of paths to the common good, many of them also self interested, so that good intentions may not produce much harmony, though it may contribute significantly to the checking function of the separation of powers.

This may be the case, even though redelegation usually occurs far from the general public's view. As another scholar observed, "the central government was most effective when its authority went unnoticed or remained hidden or was quietly obscured." ${ }^{36}$ Redelegation seems more common in education, environmental, and public health policy than in tax and fiscal policy, ${ }^{37}$ and often the public is quite unaware of what has taken place.

$30 \quad I d$. at 6.

31 Striking down the law would "produce the utmost confusion in the business of the entire country.” Field v. Clark, 143 U.S. 649, 697 (1892).

32 Blake Emerson, The Public's Law: Origins and Architecture of Progressive DEMOCRACY 149 (2019).

33 Id. at. 65.

34 James M. Landis, The Administrative Process 99 (1938).

35 As Congress consists mostly of millionaires and the bureaucracy is staffed by the middle class, the unelected bureaucracy may seem more representative than the elected Congress.

36 Brian Balogh, A Government Out of Sight: The Mystery of National Authority in Nineteenth Century America 52 (2009).

37 David Epstein \& Sharyn O’Halloran, Delegating Powers: A Transaction Cost Politics Approach to Policy Making under Separate Powers 198-99 (1999). 
Third, Redelegators believe that the political process adequately protects against abuse because, sensitive to the threat, Congress will "adequately police itself" ${ }^{\prime 38}$ through standard political means, chiefly, procedural rules. ${ }^{39}$ Congress, for instance, might delegate power to competing agencies, forcing each to monitor the other and involve Congress in the process. Or it might impose high burden of proof standards that would confine the agency's ability to act. Or it might impose limitation riders that prevent agencies from spending for specific purposes. ${ }^{40}$ And there is always the formidable power of the purse.

Redelegators admit that widespread redelegation may leave the impression of a joint judicial-congressional abdication of responsibility. But they point to studies of Congress that suggest that congressional oversight of delegation, even under these circumstances, can be effective. Barry Weingast and Mark Moran argue that agencies understand that Congress can punish them if they veer too far from its intent, and believe that even though punishment may be uncommon, the hazard remains potent. ${ }^{41}$ J.R. DeShazo and Jody Freeman support this view. ${ }^{42}$ Mathew McCubbins, Roger Noll, and Weingast point to the Administrative Procedure Act, which renders regulation easier for members of Congress and others to monitor, evaluate, and influence. ${ }^{43}$ From this perspective, the fact that Congress rarely intervenes structurally to reverse redelegation may be construed as evidence that the agencies are acting in accordance with its wishes. The problem is, however, that these studies are dated and rather narrow in focus. From 1973-1997, Presidents issued about a thousand executive orders; Congress tried to reverse thirty-seven of these; it succeeded in three instances. ${ }^{44}$ The effectiveness of congressional oversight is not established.

Fourth, Redelegators claim that their approach serves democracy: the President is democratically elected, and can be held accountable for the performance of agencies operating under his direction. ${ }^{45}$ This is said to be especially true in the current era of the never ending campaign, for the President will always focus first on political strategy, wanting to avoid driving away his supporters, and this will be reflected in the administrative decisions he and his aides take. The vast proportion of these decisions proceed with little or no public awareness, in a context in which small, well organized groups combat for advantage. Here, though knowledge,

38 Daryl J. Levinson \& Richard H. Pildes, Separation of Parties, Not Powers, 119 Harv. L. ReV. 2311, 2359 (2006).

39 Mathew McCubbins, Roger Noll, \& Barry Weingast, Administrative Procedures as Instruments of Political Control, 3 J. L. Eco 243 (1987); Mathew McCubbins et al., Structure and Process Politics and Policy: Administrative Arrangements and the Political Control of Agencies, 75 VA. L. Rev. 431 (1989).

40 Jason A. Macdonald, Limitation Riders and Congressional Influence over Bureaucracies, 104 Am. Pol. Sci. Rev. 766 (2010).

41 Barry R. Weingast \& Mark J. Moran, The Myth of Runaway Bureaucracy: The Case of the FTC, 8 REG. 33 (1982).

42 J.R. DeShazo \& Jody Freeman, The Congressional Competition to Control Delegated Power, 81 Tex. L. Rev. 1443 (2003).

43 McCubbins et al., Administrative Procedures, supra note 39, at, 253-64.

44 Terry M. Moe \& William G. Howell, The Presidential Power of Unilateral Action, $15 \mathrm{~J}$. L., Eco., \& ORGS. 132, 165-66 (1999).

45 Jerry L. Mashaw, Prodelegation: Why Administrators Should Make Political Decisions, 1 J.L. ECON \& ORG. 91, 95 (1985). 
experience, and skill will be indispensable, they can hardly banish political accountability, which leaders naturally rank as a top priority.

Congress is also democratically elected, and can (at least, in principle) be held accountable for its oversight of agencies. Does the overwhelming odds that incumbents will be reelected suggest that members of Congress pay close attention to issues of redelegation or, instead, that they can afford to ignore them? Can we infer that the silent public approves of the redelegation or merely that it is indifferent or uninformed? In the early twentieth century, Progressives applauded redelegation because their mantra was expertise, not politics, ${ }^{46}$ and the Court has sometimes seemed taken with this view. ${ }^{47}$ To some extent, the cliché of expert efficiency/ politics trade-off is exaggerated. It is true that politicians may pursue politically advantageous goals at the expense of rational policy, politics trumping expertise. But it is also true that politicians may attack bureaucratic inertia and force agencies to move expeditiously, politics supporting expertise. Indeed, efficiency may be good politics, whether in snow removal after a blizzard or in confronting a covid-19 crisis. In any case, it is hard to avoid politics. The alternative to presidential decision making is frequently not administrative expertise but congressional decision making, and the same can be said for congressional decision making. Both kinds of decision making involve democracy essentially to the extent that interest group competition counts as democracy.

Does this, then, disconnect redelegation from democracy? Redelegators think not, for though the public is doubtless ignorant about the literal workings of the massive agencies, they know enough about their programs to form a judgment. They like Social Security and Medicare, for example, and though they may not be fond of large bureaucracies, they understand that these programs require them. To the extent that opposition to the administrative state rests on its practical accountability problems, it must confront the more pressing fact of the approval of these programs.

More broadly, the defenders of redelegation recall the claims for judicial self restraint made by James Bradley Thayer in a renowned 1893 article, when he urged courts to declare acts of lawmakers unconstitutional only when they "have not merely made a mistake, but have made a very clear one - so clear that it is not open to rational question." "48 If the statute did not plainly violate the Constitution, courts should give it the benefit of the doubt, its wisdom, workability or morality being none of their business. ${ }^{49}$ Thayer justified this by pointing to the lawmakers' electoral accountability, the risk that judicial activism might undermine the courts' nonpolitical appearance, the slow pace of litigation, and the belief that in the end courts cannot do much good though they might promote irresponsibility among lawmakers and paternalism among the public.

It is but a short step from deferring to Thayer's lawmakers to deferring to their offspring, the agencies. ${ }^{50}$ As one of the most prominent advocates of this

\footnotetext{
LANDIS, supra note 34, at 23.

See, e.g., Motor Vehicle Mfr. Ass'n v. State Farm Insurance, 463 U.S. 29 (1983).

48 James Bradley Thayer, The Origin and Scope of the American Doctrine of Constitutional Law, 7 Harv. L. Rev. 129, 144 (1893).

49 Id. at 143.

50 Henry P. Monaghan wrote that in administrative matters, the judge's task is not to produce "an independent judgment rule; it is in fact quite consistent with a clear-mistake standard." Marbury and the Administrative State, 83 Colum. L. Rev. 1, 9 (1983).
} 
position declared, in a case involving rate fixing at stockyards, "This is a task of striking a balance and reaching a judgment on factors beset with doubts and difficulties, uncertain and speculative. . . . Congress has put the responsibility on the Secretary [of Agriculture] and the Constitution does not deny the assignment." Similarly, a leading study concluded, "agencies should be able to make policy as they see fit, unless there are very clear reasons indeed for courts to intervene." ${ }^{52}$ Administrators, after all, unlike judges, may have to decide under difficult, even stressful circumstances. As for redelegation's opponents, advocates dismiss them as "inebriated by an excessive intake of principle." ${ }^{3} 3$

Courts, the Redelegators believe, have been solidly in their corner. Marshall Field v. Clark (1892) saw the Supreme Court uphold a statute that directed the President to determine whether tariffs on American goods could be deemed "reciprocally unequal and unjust," and if so, to suspend the importation of the commodities "for such time as he may deem just." 54 The Court held that the statute did "not, in any real sense, invest the President with the power of legislation [because] Congress itself prescribed, in advance, the duties to be levied." ${ }^{55}$ This holding was reinforced in Keogh v. Chicago \& Northwestern Railway Co. (1922), ${ }^{56}$ where the Supreme Court protected agency set rates and tariffs of service against private consumer lawsuits alleging unreasonable or even unlawful actions. This so-called filed rate doctrine, assigning discretion to agencies and not courts, has had the effect of "keeping regulation to the regulators" 57 in such vast areas as transportation, telecommunications, utilities, and insurance, and is clearly more a legislative than an executive function.

Six years after Keogh, the Court ruled in J.W. Hampton, Jr. \& Co. v. United States (1928), which involved a company that imported barium oxide and complained, when the collector of customs charged six cents per pound, two cents per pound more than fixed by congressional statute. The statute also gave the President authority to "equalize ... differences in costs of production in the United States and the principal competing country." ${ }^{58}$ Hampton thought this constituted an invalid delegation of the legislative power by Congress to the President, as Article I assigns Congress and not the President "the power to lay and collect taxes, duties, imposts, and excises."

Chief Justice Taft, a former President, acknowledged the nonredelegation rule, ${ }^{60}$ but emphasized the practical exigencies involved in implementation. ${ }^{61} \mathrm{He}$ found that the President was not involved in "the making of law. He was the mere

\footnotetext{
Frankfurter, J., United States v. Morgan, 298 U.S. 409, 417 (1941).

52 Adrian Vermeule, LaW's Abnegation: From LaW's Empire to the Administrative StATE (2016). "If the constitutional institutions, operating as they were set up to operate, have decided that such an arrangement is both valid and wise, then respect for the separation of powers counsels approval for the arrangement."

53 Id. at 72.

54 Supra note 31 , at 691.

$55 \quad I d$. at 692.

56 Keogh v. Chicago \& Northwestern Railway Co., 260 U.S. 156 (1922).

57 Kevin M. Decker, Recent Developments in Minnesota Law: Filed Rare Doctrine: Leaving Regulation to the Regulators, 34 Wm. Mitchell L. Rev. 1351, 1352 (2008).

58 J.W. Hampton, Jr. \& Co. v. United States, 276 U.S. 394, 401 (1928).

59 U.S. Const. art I, $\$ 8$.

60 Supra note 58, at 405-6.

$61 \quad$ Id. at 407.
} 
agent of the law-making department." "If Congress shall lay down by legislative act an intelligible principle ... such legislative action is not a forbidden delegation of legislative power." ${ }^{63}$

When subsequent courts found intelligible such principles as "public interest, convenience, or necessity," ${ }^{4}$ "fair and equitable" prices, ${ }^{65}$ "public interest," 66 "just and reasonable" natural gas rates, ${ }^{67}$ "excess profits, ${ }^{" 68}$ or "requisite to protect the public health [and] allow an adequate margin of safety," ${ }^{\prime \prime}$ it seemed that the justices had all but dismissed the "toothless" for instance, the Feed and Forage Law, ${ }^{71}$ passed after the Civil War to allow soldiers to graze their horses when Congress was not in session, and since used in support of wars in Vietnam, Iraq, and Haiti. ${ }^{72}$ As Justice Scalia put it in a case involving indeterminate sentencing, "while the doctrine of unconstitutional delegation is unquestionably a fundamental element of our constitutional system . . . we have almost never felt qualified to second-guess Congress regarding the permissible degree of policy judgment that can be left to those executing or applying the law." ${ }^{\text {.73 }}$

A half century after Hampton, redelegation was strengthened in Motor Vehicle Manufacturers Association v. State Farm Mutual Automobile Insurance Co. (1983) ${ }^{74}$ In the National Traffic and Motor Vehicle Safety Act of $1966,{ }^{75}$ Congress directed the Secretary of Transportation to issue "reasonable, practicable and appropriate" motor vehicle safety standards, the Secretary delegated this power to the National Highway Transportation Safety Administration (NHTSA), and the Court held that it would uphold the redelegation unless it were arbitrary and capricious, a very low standard. ${ }^{76}$

That the case involved a double redelegation - from Congress to the Secretary of Transportation to the NHTSA - seems to the Court to have made no difference. This is significant for two reasons. First, such double redelegations, usually

Id. at 411 .

Id. at 409 .

CBS/NBC v. FCC, 319 U.S. 190, 225-26 (1943).

Yakus v. United States, 321 U.S. 414, 427 (1944).

6 N.Y. Central Securities v. United States, 287 U.S. 12, 24 (1932).

FPC v. Hope Natural Gas, 320 U.S. 591 (1944).

8 Lichter v. United States, 334 U.S. 742,783 (1948).

69 Whitman v. Am. Trucking Ass'ns, 531 U.S. 457, 472, 476. It is not obvious that these principles were more intelligible than those of the NIRA struck down in 1935. See Pub. L. 73-67, § 3, 48 Stat. 195 (1933).

70 Watts, supra note 12 , at 1006.

71 Pub. L. 91-379, 84 Stat. § 799 (1868).

72 Louis Fisher, Department of Defense Readiness Preservation Authority 3 (Cong. Res. Serv., Apr. 1995).

73 Scalia, J., dissenting, Mistretta v. United States, 488 U.S. 361, 415-16 (1989). In Crowell v. Benson, Chief Justice Hughes held that courts would review administrative questions of law and agencies questions of fact (aside from jurisdictional and constitutional facts). But this distinction broke down because the laws and facts are often deeply intertwined. Vermeule, supra note 52, at 28-29.

74 Motor Vehicle Manufacturers Association v. State Farm Mutual Automobile Insurance Co., 463 U.S. 29 (1983).

75 National Traffic and Motor Vehicle Safety Act, 80 Stat. $§ 718$, as amended, 15 U.S.C. 1381 et seq. (1976 ed. \& Supp. V).

76 Justice White concluded that the NHTSA had failed to meet this low standard. 
flowing from Congress to the President to an agency, have "become ... pivotal to presidential leadership and ... central to an understanding of presidential power." 77 Second, the principal-agent issues behind the opposition to redelegation are plainly amplified, when the process occurs twice. Elena Kagan, in an article that appeared before she joined the Supreme Court, argued for a kind of reverse redelegation, in which "a statutory delegation to an executive agency official ... usually should be read as allowing the President to assert directive authority." "She believed that "the new presidentialization of administration rendered the bureaucratic sphere more transparent and responsive to the public, while also better promoting important kinds of regulatory competence and dynamism." 79

What is established, by history if not by law, is that the President as chief executive possesses inherent executive powers involving management, covering, for example, agenda setting, staffing, information gathering, and preparing for the future. He is not a passive instrument of Congress, but, on the contrary, is supposed to supply what Hamilton in Federalist 70 called "energy." ${ }^{\prime 0}$ As public opinion leader, head of his party, possessor of such formal powers as the veto and the executive order, and chief of the bureaucracy, the President can call on vast resources and by any measure is an extraordinarily imposing political figure. He may use these powers not in response to Congress, but as a means of pushing Congress to the sidelines, for example, by issuing executive orders that create a new status quo for Congress to deal with. Congress may regard the President as constitutionally tasked to carry out its will, but he likely sees Congress as tasked to carry out his will. To the Redelegators, all this underlines the futility of opposing redelegation.

What are courts to do? The redelegators believe that courts have a significant role to play only rarely. Sometimes, they observe, even apparently sensible judicial responses turn counter productive. For example, to address fears of interests capturing agencies, courts began "providing a surrogate political process to ensure the fair representation of a wide range of affected interests." ${ }^{\prime 1}$ The point was not to exclude politics from administration, which seemed both impossible and undesirable, but to maximize political participation as a token of fairness. It was a Madisonian solution of factions checking factions ${ }^{82}$ However, this approach also exacerbated the difficulties of assembling winning congressional coalitions, making it harder than before for Congress to get beyond mundane, narrow concerns. It also made it harder for agencies to act in its place because the burden of providing materials and responding to opponents plus the risk of alienating supporters discouraged them from innovating or doing anything decisive. Meanwhile, the interests were quite satisfied with the focus on mundane issues because this generally meant that they faced no fundamental challenges or organized opposition.

In short, when courts acted to open the process, the agencies and interests tended to respond to pressure for change with their own effective work-arounds designed to further their own, often narrow interests. As a result, the formal,

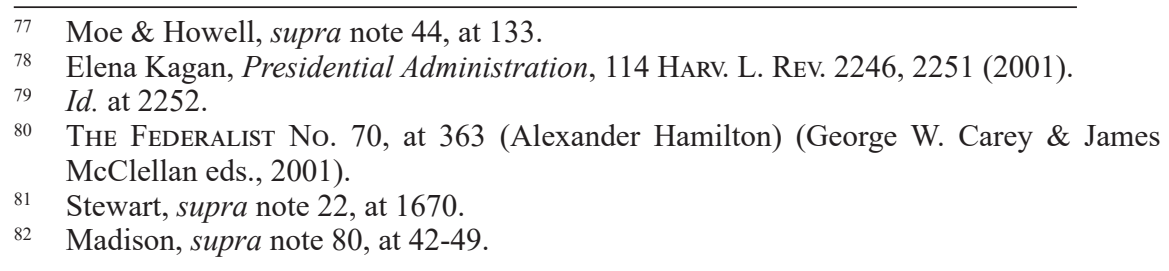


transparent procedure was often superseded by informal agency-interest contacts preceding the actual proposals, frustrating the purpose of the reforms but permitting small things to get done.

\section{THE NONREDELEGATORS}

The nonredelegators, for their part, also emphasize four points. First, they maintain that the kind of broad redelegation that is commonplace today contravenes the clear intent of the Constitution. Article I, section 1 begins, "All legislative powers herein granted shall be vested in a Congress of the United States." ${ }^{33}$ While the text explicitly neither grants nor denies Congress the authority to redelegate these powers to other actors, "no other branch of government is given power to legislate." " $\mathrm{A}$ few lines later, the incompatibility clause in Article I, section 6 reinforces this point by barring members of the executive branch from serving in the legislative branch and vice versa. Further, the Take Care clause in Article II binds the President to take care that the laws are faithfully executed, that is, to ensure that the executive branch honors the purpose and text enacted by Congress. "The essence of the legislative authority," wrote Hamilton in Federalist 75, "is to enact laws, or, in other words, to prescribe rules for the regulation of society." ${ }^{85}$ Thus, the Constitution presumes that "only the people can delegate legislative power [and therefore that] the legislature cannot delegate its powers away because legislative power was never fully alienated by the people." 86

From this perspective, even redelegation's apparent advantage in being far more rapid and less cumbersome than ordinary legislation has a downside; for its very ease of implementation counters the constitutional goal endorsed by bicameralism that law have "broad support" before its enactment. ${ }^{87}$ Too, the Administrative Procedure Act states that "the reviewing court shall decide all relevant questions of law," ${ }^{88}$ and the Supreme Court bluntly announced that the "legislative power of Congress cannot be delegated." ${ }^{89}$ It is one thing for the branches to conflict over specific policies; it is far more serious when they conflict over their legitimate areas of jurisdiction. "There is now general agreement about the necessity for delegated legislation"? ?90 Well, not exactly.

Second, the Nonredelegators often turn to an historical argument, perhaps

U.S. CONST., art. I.

84 Martin H. Redish, The Constitution as Political Structure 135 (1995).

85 Hamilton, supra note 80, at 387.

86 Joseph Postell, "The People Surrender Nothing": Social Compact Theory, Republicanism, and the Modern Administrative State, 81 Mo. L. Rev. 1003, 1013 (2016).

87 Brett M. Kavanaugh, Our Anchor for 225 Years and Counting: The Enduring Significance of the Precise Text of the Constitution, 89 Notre Dame L. Rev. 1907, 1909 (2014).

885 U.S.C.A. § 706. Congress may have considered agencies almost seamless extensions of the legislature for supplementary legislation. DAVID H. Rosenbloom, Building A Legislative-Centered Public Administration: Congress and the Administrative State, 1946-1999 2 (2000). In this, opponents to redelegation believe, Congress was mistaken.

89 United States v. Shreveport Grain \& Elevator Co., 287 U.S. 77, 85 (1932). In this case, the Court upheld the delegation.

90 Stewart, supra note 22, at 1669. 
citing John Locke: "The legislative cannot transfer the power of making laws to any other hand; for it being but a delegated power from the people, they who have it cannot pass it over to others .... [N]or can the people be bound by any laws but such as are enacted by those whom they have chosen and authorized to make laws for them." "91 A century and a half later, Tocqueville expressed fears that an administrative state could impose "a more insufferable despotism . . . than any which now exists in the monarchical states of Europe." 92

The most influential early writer, however, was undoubtedly the English constitutional scholar, A.V. Dicey, whose Introduction to the Study of the Constitution appeared in eight editions from 1885-1915. Dicey believed that the principles of parliamentary sovereignty and the rule of law left no room for the massive delegation to agencies that generates administrative law, displacing the common law. The United States, of course, lacks a principle of parliamentary sovereignty, and Dicey in any event seems to have seriously underestimated the breadth of administrative law in Britain, ${ }^{93}$ but what travelled well was his condemnation of the practice as incompatible with the rule of law and liberty. Dicey's view echoes in such statements as this from Gary Lawson: "The modern administrative state, without serious opposition, contravenes the Constitution's design." 94

This position was given its most thorough historical grounding in Philip Hamburger's polemical Is Administrative Law Unlawful? (2014), which aimed even deeper than raising questions of constitutionality. In Hamburger's view, the administrative autonomy of the modern American state is a direct descendant of the British kings' claims to royal omnipotence, claims rejected by Parliament in its Glorious Revolution and by America's Framers in their Constitution. Of course, kings always insisted that they would respect their subjects' rights and spoke of the practical necessity of their unilateral regulations, but Hamburger calls these mere rationalizations for royal power grabs. For him (as for Dicey), the existence of the administrative state threatens nothing less than the principle of "liberty under law." 95 Today, agencies issue rules unmoored to legislation, and courts do nothing about it in an "abandonment of judicial office." ${ }^{96} \mathrm{He}$ believes that "step-by-step corrections" by courts may reverse the trend, though given their deference to administrators, he is not very optimistic. ${ }^{97}$ Hamburger, it would seem, quarrels not only with excessive or abusive delegation, but almost (but not quite) with redelegation itself, for even statutorily authorized regulations he sees as imperiling the rule of law and should be avoided.

The Supreme Court has frequently announced its support for the nonredelegation principle. "That Congress cannot delegate legislative power to the President is a principle universally recognized as vital to the integrity and maintenance of the

91 John Locke, Two Treatises of Government 141 (Peter Laslett ed., Cambridge Univ. Press 1988) (1690).

92 TOCQUeVILLE, supra note 23, at 316.

93 Harry W. Arthurs, "Without the LaW": Administrative Justice and Legal Pluralism in Nineteenth Century England chs. 4-6 (1985).

94 Gary Lawson, The Rise and Rise of the Administrative State, 107 Harv. L. Rev. 1231, 1231-2 (1994).

95 Philip Hamburger, Is Administrative LaW Unlawful? 496 (2014).

$96 \quad I d$. at 316.

97 Id. at 491. 
system of government ordained by the Constitution." "98 "[T]he lawmaking function belongs to Congress . . . and may not be conveyed to another branch or entity." ${ }^{99}$ The vesting clause "permits no delegation of those [legislative] powers." 100 These declarations of principle, however, retain their purity only because they have not been put into practice. From 1942-1996, Presidents issued about 4,000 executive orders; eighty-six were challenged in the courts; fourteen of these challenges succeeded. ${ }^{101}$

Third, nonredelegators dispute the contention that the political process keeps redelegation within acceptable bounds. Congress, they admit, has ultimate control over the structure and funding of agencies, and can use hearings and speeches to reward and embarrass. But in practice the incentives for congressional action are ordinarily too sparse to justify these actions. Occasionally, as with Hurricane Katrina, administrative performance will affect large numbers of voters in direct and obvious ways, and frequently, particular interests may motivate members to act on specific regulations, as with the recent relaxation of regulations affecting the production and use of coal. ${ }^{102}$

Regulations involving microeconomic redistribution invariably mean that benefits are concentrated in a fairly small minority, while costs are diffused in a fairly large majority. As it is rational for the minority to work hard to receive substantial benefits, so is it rational for majorities absorbing tiny costs to ignore them. The larger the society and the more complex the regulations, the more the asymmetry is magnified, so that today, it is vastly greater than it was at the Founding. What results is intense, well organized, narrowly targeted minorities that nearly always triumph over unorganized, indifferent majorities. These triumphs tend to be long lasting because the minorities who benefit tend to feel much more intensely than their opponents. Administration, in the sense of addressing special purpose problems, is inherent in governing, but it is inherently biased in favor of the interests it regulates.

Redelegators may believe that it would be "implausible"103 for Congress to relinquish authority when it could avoid it. One problem with this, according to the nonredelegators, is that members of Congress understand that they cannot always avoid it, for obviously they lack the time, energy, knowledge or experience required to assume the indispensable regulative function. Sometimes, redelegation will be actively pursued by the agencies. Perhaps, they have not been given the resources required to carry out Congress' will because of a declining economy or a congressional compromise, consisting of bold legislation and tepid funding, that leaves them feeling forced to follow their own less costly path. Perhaps, the agencies are unable to determine precisely what Congress wants because Congress

98 Marshall Field, supra note 31, at 692.

99 Loving v. United States, 517 U.S. 748, 758 (1996).

100 Whitman, supra note 69, at 472.

101 Moe \& Howell, supra note 44, at 175.

102 Oliver Milman, Trump Administration Scraps Obama-Era Regulation on Coal Emissions, Guardian, Aug. 21, 2018, available at https:/www.theguardian.com/usnews/2018/aug/20/trump-coal-emissions-power-plants-rules-obama.

103 Thomas W. Merrill, Rethinking Article I, Section 1: From Nondelegation to Exclusive Delegation, 104 Colum. L. Rev. 2097, 2148 (2004). 
itself may not have made its goals known, on account of its own ambivalence. ${ }^{104}$ Perhaps, the agencies' personnel differ as to the extent to which they are restrained by Congress ${ }^{105}$ or conclude that Congress' instructions conflict with the agency's fundamental mission. The agencies' failure to defer to Congress, in short, cannot routinely be attributed to some nefarious agency intent.

On the other hand, agencies may become so ossified "that informal rulemaking has become so encumbered by procedural and analytic requirements that it is no longer capable of delivering the results expected of it," 106 and this ossification causes it to go its own way. The most ambitious study of the phenomenon, an analysis of all redelegating statutes concerning the Interior Department from 1947-1987, concluded that "mandatory delegations of regulatory authority more reliably prompt agencies to promulgate at least one regulation in response to the statute than do permissive delegations [but] even in the case of mandatory delegations, agencies routinely fail to promulgate rules." 107 "Congress rarely gives much thought ... to finetuning the amount of discretion afforded to the agency," 108 often failing even to set deadlines. However, whether the agencies discussed in this study actually exceeded their mandate is not clear, and the data also are quite old. That Congress adequately protects itself against agency redelegation is certainly not well established.

Members of Congress also may have their own reasons for favoring redelegation. For example, they may welcome the opportunity to pass contentious, complex, and potentially costly decisions on to other bodies, "avoid[ing] or at least disguis[ing] their responsibility for the consequences of the decisions"109 and finding that the exercise of power comes at too high a price. ${ }^{110}$

Also, redelegation may enhance the power of individual members, for redelegations "create administrative discretion, discretion that members of

104 David B. Spence, Agency Policy Making and Political; Control: Modeling Away the Delegation Problem, 7 J. Pub. Admin. Res. \& Theory 199 (1997).

105 Joshua D. Clinton, David E. Lewis \& Jennifer L. Selin, Influencing the Bureaucracy: The Irony of Congressional Oversight, 58 Aм. J. PoL. ScI. 387 (2014).

106 Jerry L. Mashaw \& David L. Harfst, From Command and Control to Collaboration and Deference: The Transformation of Auto Safety Regulation, 34 YALE J. REG. 167, 170 (2017); Richard J. Pierce, Jr., Seven Ways to Deossify Agency Rulemaking, 47 Admin. L. REV. 59 (1995).

107 Jason Webb Yackee \& Susan Webb Yackee, From Legislation to Regulation: An Empirical Examination of Agency Responsiveness to Congressional Delegations of Regulatory Authority, 68 Admin. L. REv. 395, 437 (2016).

108 Id. at 442.

109 Morris P. Fiorina, Group Concentration and the Delegation of Legislative Authority, in Regulatory Policy and the Social Sciences 175, 187 (Roger G. Noll ed. 1985). See also R. Douglas Arnold, The Logic of Congressional Action 101 (1990).

110 Thus, Congress has been castigated for failing to specify the requisite tradeoffs involving the Clean Air Act, dispatching the central issue to the Environmental Protection Agency. David Schoenbrod, Power Without Responsibility: How Congress Abuses the People Through Delegation 58-81 (1993). On the other hand, members will tend not to delegate redistributive policies, where they might be rewarded with campaign and other contributions. Alberto Alesina \& Guido Tabelllini, Why Do Politicians Delegate? 12-15 (NBER Working Paper No. 11531, Aug. 2005). However, the authors suggest that trade policy fits this category, though Congress dealt vast discretionary powers in this area to the President in the Trade Expansion Act (1962). Pub. L. 87-794, 76 Stat. 872. 
Congress can influence through a variety of formal and informal mechanisms." 111 Redelegation to agencies, in other words, may provide members of Congress with opportunities to intervene and deliver private goods to favored interests, who can help them, bypassing the larger legislative function of providing public goods. Instead of being merely one member of Congress with merely one vote, a member can exert real if limited influence, gaining the gratitude of the interest helped. This intervention will almost certainly occur in secret, further frustrating efforts at democratic accountability while facilitating congressional influence.

There is also the question of how Congress chooses to oversee its delegation. Will it follow the police patrol model, intervening on its own authority to ensure that its intentions are being followed? This type of oversight might be effective, but it will also prove costly in what it demands from members, in time, energy, and rejected alternatives. Or Congress might favor the fire alarm approach, descending on agencies when a serious problem has been brought to its attention. This will be much less costly to the members, but in foreswearing prevention, it may also be much less effective. ${ }^{112}$

When redelegations undermine legislation, they weaken Congress by attacking its credibility; no longer can interests trust Congress to ensure that the compromises and arrangements necessary for legislative enactment will be honored in implementation. ${ }^{113}$ Indeed, the undermining is a kind of humiliation, for the political establishment will well understand what Congress has lost. "Delegation allows members to uncouple their personal political effectiveness from the success of Congress as an institution," 114 and so redelegation tends to diminish if not trivialize the role of Congress, leaving members to focus on specific administrative carve-outs. Perverse incentives reinforce each other. What is good for members is not necessarily good for Congress as an institution. The executive branch is incentivized to redelegate, and members of Congress are incentivized to let them. With the executive involved aggressively in rule making and the legislature intervening in administration, the core of the separation of powers is reversed.

Yet because redelegation emphatically strengthens the executive, the checking function of the separation of powers is undermined. The general rule may be volenti non fit injuria (no wrong is done to one who consents), and so if Congress does not complain, why bother? But the question is not whether Congress is wronged but whether the Constitution is wronged by making it harder to maintain a vigorous separation of powers.

A pair of striking examples underline the lack of confidence in the ordinary political process. In The Bomb, Fred Kaplan describes how a low ranking civilian Pentagon aide in the George H.W. Bush administration convinced his superior to find out what targets were specified in the Single Integrated Operational Plan,

111 Neomi Rao, Administrative Collusion: How Delegation Diminishes the Collective Congress, 90 N.Y.U. L. Rev. 1463 (2015). Of course, the enhanced power of individual members comes at the cost of diminished power for Congress as a collective institution.

112 Mathew D. McCubbins \& Thomas Schwartz, Congressional Oversight Overlooked: Police Patrols versus Fire Alarms, 28 Am. J. PoL. Sci. 165 (1984).

113 For example, Dodd-Frank, which created the Consumer Financial Protection Bureau, expressly denied it authority over financing by car dealers; the CFPB nonetheless asserted control over auto financing until the Trump administration repealed the regulations.

114 Rao, supra note 111, at 1496. 
the Defense Department's nuclear war plan. Apparently, no military or civilian bureaucrat nor any President had thought to look into this. What was found was that the Strategic Air Command, which possessed 10,000 nuclear warheads, had simply decided to use all of them, without reference to a national nuclear strategy, and that many of the targets made no sense (for example, Moscow and vicinity was set to get 689 warheads, and an Arctic airbase that was unusable most of the year was to receive seventeen warheads). The inquiry led to modifications of the strategy, but it largely persisted through the Obama administration. ${ }^{115}$

A study of Congress' Safe Drinking Water Act as applied to Flint, Michigan is also harrowing. ${ }^{116}$ Congress delegated authority to develop clean water standards to the Environmental Protection Administration (EPA), which, in turn, redelegated it to state and local agencies plus private consultants. The EPA reviewed Michigan's plan only once, and was not officially informed when Flint's water quality degraded, leaving the matter to the state, which failed to ensure compliance with federal standards. The EPA could have insisted on back-up enforcement, but did not, even after it learned of the state's failure. The state and county health department, Flint's city council, and private consultants, indeed, all interested parties, also failed to act. Despite the vast, new found capacity of technology to improve rule making, implementation, and monitoring of environmental law, ${ }^{117}$ the result was dangerous levels of lead and other chemicals that polluted Flint's water supply for years and destroyed the government's credibility among the community it served. The lesson is not simply that redelegation from the EPA failed, but that simple and unavoidable delegation from Congress to the EPA also failed.

Fourth, Nonredelegators reject the idea that redelegation is fundamentally democratic. Will presidential or congressional campaigns confer democratic mandates on the victor that extend to administrative issues? This is very doubtful. ${ }^{118}$ The President, in any case, ordinarily does not deal with Congress collectively, but with coalitions composed of members, each with his own reelection, partisan base, and institutional influence to secure. Also, the President's heterogeneous national constituency makes him less accountable to the public than are members of Congress, with their much smaller and more compact constituencies.

If we conceive democracy in broader terms, say, at the level of the general public, it would seem obvious that the general public has little meaningful participation in the administrative work of redelegation, and likely is aware of such work only in the vague way that it is aware that food ultimately does not come from the supermarket. It is quite unrealistic, then, to expect that the general public hold administrators accountable through its capacity to elect and defeat Presidents

115 Fred Kaplan, The Bomb: Presidents, Generals, And The Secret History of NuCleAR WAR ch. 8 (2020).

116 Hannah, J. Wiseman, Delegation and Dysfunction, 30 Yale J. Reg. 233, 260-65 (2018)

117 Daniel C. Esty, Environmental Protection in the Information Age, 79 N.Y.U. L. Rev. 115 (2005).

118 The preeminent American political scientist has dismissed presidential mandates as a myth. Robert A. Dahl, The Myth of the Presidential Mandate, 105 PoL. ScI. Q. 355 (1990). As for Congress, initially many members may act as if an election were a mandate, but they gradually return to their normal policy positions. David A.M. Peterson, Lawrence J. Grossback, James A. Stimson \& Amy Gangl, Congressional Response to Mandate Elections, 47 Am. J. Pol. Sci. 411 (2003). 
and members of Congress. Unless we are members of a group seeking a tangible benefit, we probably are poorly informed about policies, our thoughts consisting at best of a mélange heavy on personal experiences and misinformation that we do not bother trying to rectify because it simply does not seem worth it. Does this degree of indirect, informationally problematic accountability qualify as democratic? On broad issues that strike us directly, like inflation, most people might well know and care enough to enforce a significant level of accountability. But though administrators' decisions may indirectly affect these issues, they ordinarily will be far too narrow and technical to generate much public interest, even if the public knew about them (which it in all likelihood does not).

Polarization magnifies the problem. Members of Congress may feel that tough party discipline shrinks their role as law makers, leaving intervening with agencies as one of the few remaining tasks that invigorate their sense of accomplishing something. A frontal attack on delegations to agencies may seem quixotic and not worth the substantial investment in energy and political capital, for as party loyalty tends to trump institutional loyalty, members can expect little or no support from opposition colleagues. Thus, the democratic potential of congressional action is sharply reduced.

At the same time, because polarization tends to impede congressional action, it also may incentivize the executive branch aggressively to counter the policy vacuum, moving unilaterally to issue broad regulations. For example, President Obama, faced with a recalcitrant Congress ("We can't wait"119), had his Secretary of Homeland Security issue orders granting certain privileges to so-called Deferred Action on Childhood Arrivals (DACA Dreamer) immigrants. ${ }^{120}$ As Franklin Roosevelt put it nearly eighty years earlier, "In the event that Congress should fail to act, and act adequately, I shall accept the responsibility, and I will act." ${ }^{121}$ Congress members of the President's party routinely applaud these kinds of decisions as bold actions that get things done; members from the opposing party condemn them as autocratic and unlawful. ${ }^{122}$ But the power and stature of Congress is eviscerated.

But though members may dispute specific executive actions, rarely do they seek structural changes that would make such actions impossible - possibly, because they understand that their party may soon own the White House and want the discretion that the current executive exercises. Members who intervene over specific regulations may be able to claim credit for something; those who strive to change the system likely will be unable to claim credit for anything.

119 Charlie Savage, Shift on Executive Power Lets Obama Bypass Rivals, N.Y. Times, Apr. 23, 2012, at A1.

120 Memorandum from Jeh Charles Johnson, Secretary of Homeland Security, Exercising Prosecutorial Discretion with Respect to Individuals Who Came to the United States as Children and with Respect to Certain Individuals Who Are the Parents of U.S. Citizens or Permanent Residents (Nov. 20, 2014).

121 Quoted in Joel Fleishman \& Arthur Aufses, Law and Orders: The Problem of Presidential Legislation, 40 L. \& CONTEMP. Probs. 1 (1976).

122 Mike Lillis, 113 Republicans Back Lawsuit against Obama’s Immigration Actions, THE HiLl, May 11, 2015. 


\section{LOOKING TO THE FUTURE}

For a number of years, it was liberals who seemed most appalled by the ever expanding practice of redelegation. Justice Douglas considered public interest "too vague a standard to be left to free-wheeling administrators. They should be more closely confined to specific ends or goals." ${ }^{23}$ James O. Freedman saw redelegation as "part of a larger social uneasiness over the impact upon American life of large organizations, within both the public and private sectors" that might eventually threaten the political system's very legitimacy. ${ }^{124}$ John Hart Ely considered redelegations to be "undemocratic, in the quite obvious sense that by refusing to legislate, our legislators are escaping the sort of accountability that is crucial to the intelligible functioning of a democratic republic," 125 and Martin Redish agreed. ${ }^{126}$ The absence of accountability, David Schoenbrod found, allowed "legislators to appear to deliver regulatory benefits without imposing regulatory costs." 127

Relatedly, the eminent political scientist, Theodore J. Lowi, thought that redelegation enabled government to buy off groups with favors, shutting out the public and forestalling wholesale attacks on such fundamental problems as racism and inequality. So long as this approach prevailed, it would be impossible to rescue the country from the resulting quagmire, which he termed "Policy without law." 128 J. Skelly Wright, a prominent judge on the D.C. Circuit whose business is largely administrative law, declared, "Ultimately, the arguments for broad delegation rest on the illusion that problems are solved by conflict avoidance." 129 But if the political branches cannot solve the problems, he asked, why assume that agencies can? And even if agencies can, this "will have been accomplished at the expense of democratic decisionmaking." 130 These liberal analysts, favoring more aggressive government action, saw redelegation as empowering regulatory bodies, which they believed were routinely captured by conservative interests.

Liberal opposition to redelegation, however, seems today to be very much a thing of the past. Instead, liberals seem more likely to insist that vast administrative discretion and redelegation are essential if society's most significant and pressing problems are to be addressed. If agencies specially equipped for the tasks are not trusted to confront the problems, they reason, who will? There are sufficient controls in place, legal and psychological, they believe, to keep the agencies in line. More controls imposed by courts lacking the requisite knowledge, skills, and experience, would hamstring the agencies, causing hardship greater than the abuses now tolerated as unavoidable costs of doing business.

Now, it is conservatives who voice their opposition. Emmett McGroarty, Jane Robbins, and Erin Tuttle believe that redelegation has been a stealth instrument that

Go East, Young Man: The Early Years 217 (1974).

James O. Freedman, Crisis and Legitimacy 262 (1978).

25 John Hart Ely, Jr., Democracy and Distrust 132 (1980).

126 ReDish, supra note 84, at 142-43.

127 Schoenbrod, supra note 110, at 10.

128 Theodore Lowi, The Politics of Disorder xviI-xviii (1974).

129 J. Skelly Wright, Beyond Discretionary Justice, 81 YALE L. J. 575, 585 (1972).

130 Id. at 586 . 
has weakened the constitutional role of the states in order to empower the central bureaucracy. ${ }^{131}$ John Marini agrees, maintaining that centralization undermines natural rights, limited government, and the separation of powers and faulting Congress for accepting the role of guardian of the administrative state. ${ }^{132}$ Steven Hayward thinks that if the process "is not stopped and reversed, it will result in the end of limited constitutional government." 133

More than this, conservatives blame redelegated administrative discretion for enabling the growth and dominance of big government and the regulatory empire that has emerged to do its work. "The rationale for this virtually complete abandonment of the nonredelegation principle is simple: Congress believes - possibly correctly that the modern administrative state could not function if Congress were required to make a significant percentage of the fundamental policy decisions." ${ }^{134}$ Redelegation might well be necessary for the modern administrative state, but conservatives do not concede that the modern administrative state itself is necessary. In fact, the very indispensability of administrative discretion to the modern state is for them the most powerful argument against it. The alternative, reliance on the market and private initiative, conservatives claim is more efficient and effective, less costly financially and otherwise, and more conducive to preserving liberty and developing strong personal character and independence.

To liberals, this argument gets things precisely backwards. They see a very broad public consensus supporting the programs identified with the administrative state. ${ }^{135}$ In addition, as an analysis of every redelegation from 1947-2012 revealed, "increased concentration of implementation authority is associated with greater ideological congruence between pivotal members of the House and Senate." 136 Accordingly, efforts to dismantle the administrative state, particularly, efforts led by unelected judges, strike liberals as profoundly anti-democratic. What gives this special bite is that these efforts, dressed in legal verbiage in court cases practically invisible to laypersons, grant the public no meaningful role and proceed almost entirely without their knowledge. That the conservatives' rationale features paeans to democracy liberals regard simply as a crowning hypocrisy.

If the dispute over delegation were merely a quarrel between abstractions, it might attract the interest only of ideologues and narrow specialists. But it has become perhaps the principal intellectual arena where the legal struggle between liberalism and conservatism is played out, "the legal equivalent of mortal combat."137 A quarter century ago, the "problem of delegation" was said to occupy "center stage

131 Emmett Mcgroarty, Jane Robbins, \& Erin Tuttle, Deconstructing the Administrative State: The Fight for Liberty (2019); Peter Wallison, Judicial Fortitude: The Last Chance to Rein in the Administrative State (2018).

132 John Marini, Unmasking the Administrative State: The Crisis of American Politics in the Twenty-First Century 43, 59 (Ken Masugi ed., 2019).

133 Steven F. Hayward, The Threat to Liberty, in 17 Claremont Rev. OF Bks. (Winter, 2016-2017).

134 Jamelle C. Sharpe, Judging Congressional Oversight, 65 Admin. L. Rev. 184 (2013).

135 Bruce Ackerman, We The People: Foundations 47-50 (1991).

136 Jordan Carr Peterson, All Their Eggs in One Basket? Ideological Congruence in Congress and the Bicameral Origins of Concentrated Delegation to the Bureaucracy, 7 LAWs 19 (2018).

137 Gillian E. Metzger, The Roberts Court and Administrative Law, Sup. CT Rev. 1 (2018).. 
in any account of public law today." 138 Years have only validated this observation and awarded it an exclamation point.

Recently, the Supreme Court has indicated that it may, at long last, revisit the redelegation issue. Gundy v. United States (2019), concerned Herman Gundy, who was convicted of giving cocaine to a minor girl and raping her. Congress' Sex Offender Registration and Notification Act of 2006 (SORNA) required all sex offenders convicted or serving prison time after its enactment to join a nationwide registry for sex offenders, but left it to the attorney general to determine whether and how the law applies to offenders convicted before its enactment. ${ }^{139}$ The attorney general decided that the registration requirement applied retroactively on an interim (2007) and then a permanent (2010) basis. Gundy failed to register, was prosecuted and convicted, and sued, charging that Congress had delegated excessive authority to the attorney general.

Speaking for a liberal plurality, Justice Kagan found that SORNA had adequately limited the attorney general's discretion by requiring him, by implication, to implement the law "as soon as he thought it feasible to do so." defined sex offender as "an individual who was convicted," 141 that is, in terms of a past conviction, it seemed reasonable for the attorney general to apply the law retroactively, and the statute's legislative history indicated that this "was front and center in Congress' thinking." 142 The redelegation was a "stopgap [addressing] practical problems . . . and nothing more," "143 which Kagan characterized as a "transitional" 144 issue. With this "intelligible principle," which "the Court has made clear [is] not [a] demanding" standard, the law "easily passes constitutional muster." "145 Seeing Gundy as a possible proxy for redelegation generally, Kagan wrote, "If SORNA's delegation is unconstitutional, then most of government is unconstitutional - dependent as Congress is on the need to give discretion to executive officials to implement its programs."146 Justice Alito concurred separately, noting that he would have been "willing to reconsider" redelegation but acknowledging that he could not say that "the statute lacks a discernible standard that is adequate under the approach this Court has taken for many years." 147

In a dissent longer than the majority opinion, Justice Gorsuch, long a foe of redelegation, argued that redelegation "undercuts" accountability, dismissing the intelligibility principle as having "no basis in the original meaning of the Constitution, its history, or even the decision from which it was plucked." "148 $\mathrm{He}$ asserted that redelegations must be "sufficiently definite and precise to enable Congress, the courts, and the public to ascertain whether Congress' guidance has been followed," 149

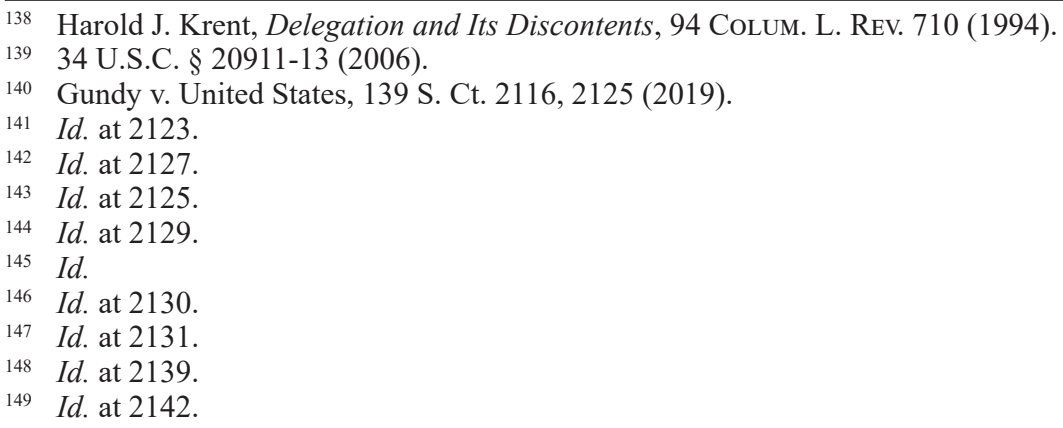


Gundy failed to change redelegation doctrine, yet it may well be the harbinger of changes to come. The very fact that the Court agreed to hear the case - the first delegation case in nearly two decades - when there was no conflict among the circuit courts indicates a readiness, perhaps an eagerness, to reconsider the issue. Moreover, the addition of Justice Kavanaugh, known for his reservations about delegation, may mean that there is now a majority supporting that position. In Paul v. United States (2019), a redelegation case the Supreme Court declined to hear, Kavanaugh, sitting as a D.C. circuit judge, declared that Gorsuch's "thoughtful Gundy opinion raised important points that may warrant further consideration in future cases." 150 Justice Thomas has also pointed out that "the Constitution does not speak of "intelligible principles [but instead] vests all legislative powers" with Congress; ${ }^{151}$ Article I "require[s] that the federal government create generally applicable rules of private conduct only through the constitutionally prescribed legislative process." 152 Justice Alito, too, has dismissed defenses of redelegation as a "mere fig leaf of constitutional justification," 153 and Chief Justice Roberts, known for his caution, has observed that "the danger [of tyranny] posed by the administrative state cannot be dismissed." 154 A majority, deeply suspicious of redelegation, may already exist.

Does "this turn against congressional delegations signif[y] a profound transformation in our political and intellectual life"? ${ }^{155}$ It depends. One option would be simply to dismantle the administrative state, on the theory that, whatever its virtues, redelegation is prohibited by the Constitution. However, this seems so radical a proposal - even a critic of redelegation admitted it would be "unlikely [and] highly disruptive"156 -- that no President or Congress has ever seriously considered it. Regardless as to whether the administrative state is in fact necessary for the well being of the public, clearly there is a durable and entrenched public consensus that thinks so. This option is plainly a nonstarter.

A second option would be to continue the status quo, pretending that there is really no constitutional problem. The Constitution bans redelegation, Justices might admit, but what Congress has done is not redelegation, but merely rule making. Nearly everyone recognizes that this verbal sleight-of-hand does not solve the problem, but rather only denies that a problem exists. This option possesses the enormous advantage of continuing things as they are, and plainly appeals to the Court's liberal faction. But it also offers nothing to its opponents, who seem unlikely to quietly surrender.

Justice Gorsuch, in his Gundy dissent, pointed to intermediate options. Highlighting the importance of the criminal nature of the regulation, he noted that

${ }_{150}$ Paul v. United States, 140 S. Ct. 342 (2019).

151 Whitman, supra note 69, at 487 (Thomas, J., concurring).

152 Dep’t of Transp. v. Ass'n of Am. R.R., 135 U.S. 1225, 1246 (2015) (Thomas, J., concurring).

153 Whitman, supra note 69, at 475 (Alito, J., concurring).

154 City of Arlington v. FCC, 569 U.S. 290, 315 (2013) (Roberts, C.J., dissenting).

155 J. Benton Heath, From the Spirit of the Federalist Papers to the End of Legitimacy: Reflections on Gundy v. United States, 114 Nw. U. L. Rev. 1723, 1727-28 (2020).

156 Justin Walker, The Kavanaugh Court and the Schechter-to-Chevron Spectrum: How the New Supreme Court Will Make the Administrative State More Democratically Accountable, 95 IND. L. J. 923, 943 (2020). 
the crime of which Gundy was convicted literally would not have existed, save for the attorney general's action. Redelegation meant that "a single executive branch official [could] write laws restricting ... liberty," notwithstanding that the Framers considered the "federal government's most dangerous power was the power to enact laws restricting the people's liberty." 157 If criminal redelegation was counted as the worst kind, why not start the carve-out here? Also, while Gorsuch did not mention it, excising criminal regulations would not affect the commercial interests that have made their peace with redelegation, and thus would entail a much lower level of political conflict.

Underpinning Gorsuch's argument was a pair of distinctions he drew: privileges versus rights and fact finding versus policy making. If privileges and fact finding were involved, he clearly would be much more likely to uphold redelegation than if rights and policy making were involved. In Gundy, he believed that rights and policy making were involved. Rejecting the intelligible principle standard as useless, he would return to "fill up the details," a test set down in a 1911 case involving grazing rights. ${ }^{158}$

Another option might be to confine redelegation to minor matters or incidental powers. As a prominent originalist put it, "Some powers are so great, so important, or so substantive, that we should not assume that they were granted by implication, even if they might help effectuate an enumerated power." 159 Following this line of reasoning, Chief Justice Roberts, in considering whether the Affordable Care Act could compel people to buy health insurance, held that forcing people to purchase something altered "the relation between the citizen and the federal government" so substantially that it constituted "a great substantive and independent" change that could only be authorized by an express provision of the Constitution. ${ }^{160}$ This rehearsed James Madison's familiar argument in the House against Hamilton's proposed Bank of the United States. Creating a bank was such a great power that it could not be implied from the Constitution, Madison said, but required explicit authorization. Congress was obliged to weigh not merely "the degree of incidentiality to an express power [but also the] degree of its importance."161 The Constitution must "condemn the exercise of any power, particularly a great and important power, which is not evidently and expressly involved in an express power."162

If I hire someone to manage my restaurant, she does not need to ask me if she has the authority to buy tomatoes. That power is incidental to her function as

157 Gundy, supra note 140, at 2131, 2133 (2019).

158 United States v. Grimaud, 220 U.S. 506, 517 (1911).

159 William Baude, Rethinking the Federal Eminent Domain Power, 122 Yale L. J. 1738, 1749 (2013).

160 Nat'l Fed'n of Indep. Bus. v. Sebelius, 132 S. Ct. 2566, 2589, 2591, 2593 (2012). But $c f$. Ginsburg, J., concurring and dissenting, at 2627.

1612 ANNALS OF CONG. 1896 (1791).

162 Id. at 1899. Hamilton's supporters strongly disagreed (see, e.g., pp. 1904, 1929-30). Concerning a bill providing for federal aid to a New Jersey copper mine, Jefferson retorted, "Congress are authorized to defend the nation. Ships are necessary for defense; mines, necessary for copper; a company necessary to work the mines; and who can doubt this reasoning who has ever played 'This is the House that Jack Built.' Under such a process of filiation the sweeping clause makes clean work." Thomas Jefferson letter to Edward Livingston (Apr. 30, 1800) (on file with the Library of Congress). 
manager. But if she wants to double the size of the restaurant or change the menu from Italian to Welsh or hire her son as chef, I might want to insist on a right of approval. Where on the spectrum between buying tomatoes and doubling the size of the restaurant does the decision cease to be incidental? If she wants to repaint the dining room, does she need to talk to me? Would it depend on whether she chose a different shade of its current white or instead a chartreuse to match the color of her daughter's hair? It is hard always to be certain where to draw the line, and as the two of us each have our own interests and perspectives, we can hardly pretend to objectivity. So it is with delineating the boundaries of incidental powers for the purpose of resolving redelegation controversies.

In FDA v. Brown \& Williamson (2000), the Supreme Court considered an effort by the Food and Drug Administration to regulate children's access to tobacco products. The Court highlighted a provision of the United States Code that "marketing tobacco constitutes one of the greatest basic industries of the United States," and concluded that Congress did not intend to delegate such a major decision to the FDA. ${ }^{163}$ Similarly, in King v. Burwell, the Court held that as the Affordable Care Act "involved billions of dollars [and] affect[ed] the price of health insurance for millions of people," ${ }^{164}$ the Court could not assume that Congress intended to delegate the rules requiring purchase of coverage to an agency. Political accountability required that Congress make the decisions.

Justice Kavanaugh has emerged as the chief proponent of the major question exception. ${ }^{165}$ When sitting on the D.C. Circuit, he dissented in a case involving an FCC rule on net neutrality, and held that given its importance, "clear congressional authorization" was required for redelegation. ${ }^{166}$ Absent this authorization, redelegation would violate the separation of powers. The very fact that redelegation would facilitate rapid policy change seems to Kavanaugh another reason to proceed cautiously, for the legislative process established in the Constitution is intended to slow passage as a means of ensuring "broad support." 167 Justice Kavanaugh's answer to the puzzle would eliminate contentious line drawing: require Congress explicitly to authorize redelegation. ${ }^{168}$ Certainly, this would clarify matters, although even here unanticipated circumstances may present silences and ambiguities that would remain unresolved.

From 2009-2017, as a political gesture congressional Republicans proposed the REINS Act (Regulations from the Executive in Need of Scrutiny) that would have necessitated that all major rules be approved via a joint resolution, making it much harder for agencies to generate regulations, but it never was adopted. ${ }^{169}$

\footnotetext{
529 U.S. 120, 137.

135 S. Ct. 2480, 2483, 2489 (2015).

165 Jonathan H. Adler, Will Kavanaugh Curb Sloppy White House Deregulation?, N.Y. Times (July 16, 2018), available at https://www.nytimes.com/2018/07/16/opinion/brettkavanaugh-supreme-court-administrative-state.html.

166 U.S. Telecom supra note 162, at 417 (D.C. Cir. 2017) (Kavanaugh, J., dissenting).

167 Kavanaugh, supra note 87, at 1910.

168 United States Telecom Ass'n v. FCC, 855 F. 3d 381 (D.C. Cir. 2016) (dissenting); Brett M. Kavanaugh, Fixing Statutory Interpretation, 129 Harv. L. Rev. 2118 (2016).

169 An interesting question is whether President Trump's travel bans could survive such a major exception test. In Trump v. Hawaii, he claimed that 8 U.S.C. $\$ .1182$ (f) authorized the President to prevent the entry of foreign nationals he considers "detrimental to the interests of the United States ... for such period as he shall deem necessary ... or impose
} 
An obvious problem with the major question approach is the absence of objective criteria for distinguishing major from minor questions. Was creating a national bank a major question? Madison and Jefferson thought so. Hamilton and Marshall thought not. Absent these objective criteria, the result of REINS might well be even more judicial subjectivity, confusion, and unpredictability.

The judicial combat over redelegation is most immediately focused on Chevron v. Natural Resources Defense Council (NRDC), decided in 1984, universally described as "the most famous doctrine in all of administrative law." 170 Before the case, it was assumed that courts had the power to determine what an ambiguous or silent regulation meant, on the theory that Congress had an intention to fit every situation and it was up to the courts to determine what the intent was. One analysis of mandamus cases decided before 1940 found that "the Court's interpretive role was essentially [nondeferential] de novo," 171 while another denied that "there is one elegant allocation of power between court and agency." 172 Sometimes, courts were deferential, and sometimes they were not.

The Chevron case arose out of the Clean Air Act of 1977, ${ }^{173}$ which empowered the EPA to issue regulations governing "major stationary sources of pollution." The EPA's regulations allowed states to treat all pollution emitting devices within a single factory as if they were encased in a single bubble; the NRDC considered the bubble approach inconsistent with congressional intent, insisting that each piece of equipment be treated as a pollution source that had to meet the pollution standard. Congress had not defined "stationary source" in a way that would have resolved the dispute, and the legislative history was inconclusive.

Justice Stevens, writing for a unanimous Court, acknowledged that if Congress' statutory intent were clear, agencies and courts had to follow it; "that is the end of the matter." ${ }^{174}$ But what if the statute is silent or ambiguous? In these cases, Stevens said, "judges - who have no constituency - have a duty to respect legitimate policy choices made by those who do." 175 Judges lack policy expertise and are not accountable to the people; agencies possess expertise and are indirectly

on the entry of aliens any restrictions he may deem to be appropriate." The provision did not define "interest" nor did it require the President to present evidence that the ban was a reasonable means to that end, but it did allow the President on his own to criminalize conduct that had not been criminal. Targeting a major policy, the provision would seem to lack an intelligible principle. Additionally, that it might imply a power to override congressionally authorized visa categories might also pose separation of power issues. Chief Justice Roberts ruled that as the provision "exudes deference to the President in every clause ... the proclamation falls well within this comprehensive delegation." 138 S. Ct. 2392, 2408 (2018). It is precisely the exuding of deference that raises redelegation concerns.

170 Adrian Vermeule, Judging Under Uncertainty: An Institutional Theory OF Legal Interpretation 201 (2006); Joshua Matz, The Imminent Demise of Chevron Deference?, TAKe CARe Blog (June 21, 2018), available at https://takecareblog.com/ blog/the-imminent-demise-of-chevron-deference

171 Aditya Bamzai, The Origins of Judicial Deference to Executive Interpretation, 126 YALE L. J. 908, 958 (2017).

172 Ann Woolhandler, Judicial Deference to Administrative Action - A Revisionist History, 43 Admin. L. Rev. 197, 245 (1991).

173 Pub. L. 95-95, 91 Stat. 685.

174 Chevron U.S.A., Inc. v. Natural Res. Def. Council, Inc. 467 U.S. 837, 842 (1984).

175 Id. at 866. 
accountable through the President; "it is entirely appropriate for the political branch of the government to make such policy choices - resolving the competing interests which Congress itself either inadvertently did not resolve or intentionally left to be resolved by the agency." 176 Courts should not impose their own interpretation of the statute, but should defer to the agency, provided only that the agency's interpretation is not arbitrary, capricious, or manifestly contrary to the statute. As a kind of default judgment, Stevens assumes that Congress has implicitly delegated authority to agencies to fill in the gaps.

Initially, conservatives lauded Chevron, perhaps because the agencies that were empowered were part of the Reagan administration. The Pacific Legal Foundation and the Mid-America Legal Foundation, both conservative think tanks, submitted amici briefs in support of deference, Justice Scalia, an expert in administrative law, defended the decision as implementing congressional intent, ${ }^{177}$ and Kenneth Starr, then with the D.C. Circuit, observed, "Unelected judges should leave the executive branch free to pursue . . . what it perceives to be the will of the people." ${ }^{178}$ By the Obama years, however, the perils of redelegation seemed clearer ${ }^{179}$

Critics have attacked Chevron and its progeny as instances of judicial abdication ${ }^{180}$ that encourage Congress and the courts to pass difficult or politically controversial policies on to the agencies, thus expanding their role as enunciators of constitutional law and empowering them at the expense of the political branches. Justice Kennedy, for instance, thought Chevron encouraged "cursory analysis" and "reflexive deference;" 181 Chief Justice Roberts pointed to the "thousands of pages of regulations [and] hundreds of federal agencies poking into every nook and cranny of daily life"; ${ }^{182}$ Gorsuch, when on the Tenth Circuit, said that Chevron permits "executive bureaucracies to swallow huge amounts of core judicial and legislative power and concentrate federal power in a way that seems more than a little difficult to square with the Constitution;"'183 and Justice Thomas declared that Chevron "wrests from courts the ultimate interpretive authority to "say what the law is' and hands it over to the executive"184 citing John Marshall in Marbury v. Madison. ${ }^{185}$ By this time, the composition of the federal judiciary had become much

176 Id. at 865-66.

177 Antonin Scalia, Judicial Deference to Administrative Interpretations of Law, 1989 DUKE L. J. 511, 517. On the Court, he also favored Chevron deference, as in Whitman, supra note 69, at 473-75 ; Gonzales v. Oregon, 546 U.S. 243, 301 (2006); City of Arlington, supra note 154, at 299.

178 Kenneth W. Starr, Judicial Review in the Post-Chevron Era, 3 Yale J. On Reg. 283, 309 (1986). See also, Douglas W. Kmiec, Judicial deference to Executive Agencies and the Decline of the Nondelegation Doctrine, 2 Admin. L. J. 269 (1988); Lawrence H. Silberman, Chevron-The Intersection of Law and Policy, 58 Geo. WASH. L. Rev. 821 (1990).

179 See, e.g., Joseph Postell, How to Limit Government in the Age Of Obama, Heritage Foundation (June 25, 2013); Founders Betrayed? New Threats to US Democracy and the Rule of Law, Am. Enterprise Inst. (Nov. 30, 2012).

180 Gorsuch, J., Gutierrez-Brizuela v. Lynch, 834. 3d 1142 (10 ${ }^{\text {th }}$ Cir. 2016).

181 Pereira v. Sessions, 138 S. Ct. 2105, 2121 (2018).

182 Arlington, supra note 154 , at 315.

183 Gutierrez-Brizuela, supra note 180 , at 1149

184 Michigan v. EPA, 135 S. Ct. 2699, 2712 (2015).

1855 U.S.(1 Cr.) 137, 177 (1803). On the other hand, if courts defer to agencies, they are saying that the agencies' interpretations of statutes are the law. 
more heavily weighted toward Republicans, perhaps explaining why conservative judges and pundits now perceived more defects in Chevron than they had noticed a few years earlier.

If the charge of judicial abdication suggests no specific remedy, more focused critiques have called for particular responses. For example, in Auer v. Robbins (1997), the Court decided that courts should defer to an agency's interpretation of its own regulations, ${ }^{186}$ and in National Cable \& Telecommunications Association v. Brand X Services (2005), the Court held that the agency's interpretation should prevail, even when it conflicted with a judicial precedent. ${ }^{187} \mathrm{~A}$ future Court might rule that these cases approve a conflict of interest that allows agencies to judge their own causes, placing them both in obvious jeopardy. In this, Chevron poses the same problem that faces redelegation generally. Is the statute sufficiently silent or ambiguous to satisfy Chevron? A dissatisfied consensus has proven difficult to translate into a satisfied consensus on a replacement. As my father used to remind me, "You can't beat something with nothing."

Prophecy is always treacherous, but it seems clear that redelegation will neither remain intact nor be entirely struck down. Hence, much of the overblown rhetoric the controversy has inspired seems beside the point, especially the back-and-forth on democracy. No one expects Congress to vastly broaden its legislative mandate nor the agencies to relinquish their administrative responsibilities. Democracy, we recognize, is more about choosing leaders than controlling their policies. We may imagine that the political branches are the great compromisers. But, as we shall see, courts compromise, too.

To delegate or redelegate? The weak-kneed reply (surprisingly) received classic expression from John Marshall: "“ It will not be contended that Congress can delegate to the courts, or to any tribunal, powers which are strictly and exclusively legislative. But Congress may certainly delegate to others, powers which the legislature may rightfully exercise itself." ${ }^{88}$ Will presidential and congressional initiatives provoke the other to greater activity? ${ }^{189}$ Is there a shared interest in effective governance? The influence of the administrative state is felt everywhere, and so though cases on same sex marriage and abortion may win the headlines, administrative law has a far greater impact on the Constitution and the every day life of Americans.

\footnotetext{
519 U.S. $452,461$.

187545 U.S. 967, 1003 (Thomas, J.). A few years later, Thomas announced that he had changed his mind. "It is never too late to surrender former views to a better considered position." South Dakota v. Wayfair, Inc., 138 S. Ct. 2080, 2100 (concurring) (2018).

188 Wayman v. Southard, 23 U.S. (10 Wheat.) 1, 42-43 (1825).

189 On the other hand, a President or an agency, after following notice rules, may simply issue regulations essentially on their own authority. Thus, even ideal legislators would need to delegate considerable authority to administrators to apply laws to a complicated, changing world. For example, the Reagan administration's aggressive assertion of administrative discretion was met by Congress less willing to delegate authority to the executive. Epstein \& O'Halloran, supra note, at 115.
} 